\title{
The genetic and molecular basis of congenital cataract
}

\author{
Base genética e molecular da catarata congênita
}

Alessandro Santana $^{1}$, Mauro Waiswol ${ }^{1}$

\begin{abstract}
Congenital cataracts are one of the most treatable causes of visual impairment and blindness during infancy, with an estimated prevalence of 1 to 6 cases per 10,000 live births. Approximately fifty percent of all congenital cataract cases may have a genetic cause. All three types of Mendelian inheritance have been reported for cataract; however, autosomal dominant transmission seems to be the most frequent. The transparency and high refractive index of the lens are achieved by the precise architecture of the fiber cells and the homeostasis of the lens proteins in terms of their concentration, stability, and supramolecular organization. Research on hereditary congenital cataract led to the identification of several classes of candidate genes that encode proteins such crystallins, lens specific connexins, aquaporine, cytoskeleta structural proteins, and developmental regulators. The purpose of this study was to review the literature on the recent advances made in understanding the molecular genetic basis of congenital cataracts.
\end{abstract}

Keywords: Cataract/congenital; Blindness/etiology; Crystallins/genetics; Gammacrystallins/genetics; Molecular biology; Genes; Mutation

\section{RESUMO}

A catarata congênita é uma das principais causas tratáveis de cegueira na infância, com prevalência estimada em 1 a 6 casos por 10.000 nascidos vivos, sendo a causa hereditária responsável por até metade dos casos. Dentre os padrões de herança já descritos para a catarata, a transmissão autossômica dominante é a mais frequente. A transparência e o alto índice refrativo do cristalino são resultados da disposição regular das fibras lenticulares e do equilíbrio homeostático; além da estabilidade e da organização supramolecular das proteínas do cristalino. Pesquisas sobre catarata congênita hereditária têm levado à identificação de várias classes de genes responsáveis pela codificação das proteínas do cristalino, tais como: cristalinas, conexinas, aquaporinas, proteínas do citoesqueleto e reguladores do desenvolvimento. O objetivo deste estudo foi a revisão da literatura sobre os recentes avanços na compreensão da base genética e molecular da catarata congênita.

Descritores: Catarata/congênito; Cegueira/etiologia; Cristalinas/genética; Gama-cristalinas/genética; Biologia molecular; Genes; Mutação

\section{INTRODUCTION}

The identification of the mutations causing childhood cataract should lead to a greater understanding of the mechanisms implicated in cataractogenesis and provide further insights into normal lens development and physiology. Moreover, gene mapping is an important step in understanding the molecular defects of age-related cataract, which also has a strong genetic component to its etiology, and in longer term may lead to the development for a medical therapy to slow lens opacification.

\section{Childhood blindness}

There are approximately 1.5 million blind children in the world; $90 \%$ of them live in developing countries ${ }^{(1-2)}$. The control of blindness in children is considered a high priority within the World Health Organization's (WHO's) VISION 2020 - The Right to Sight program $^{(3)}$. There are several reasons for this: the greatly emotional, social, and economic costs to the child, the family, and society; in addition, many of the causes of blindness in children are either preventable or treatable ${ }^{(4)}$. Although the total number of blind children is lower than of adults, the number of "blind years" due to childhood blindness is estimated to be similar to the number of "cataract blind years" in adults.

Congenital cataract is the leading cause of reversible blindness in childhood. Its occurrence, depending on the regional socioeco- nomic development, is of 1 to 6 cases per 10,000 live births in industrialized countries ${ }^{(3-5)}$, and of 5 to 15 per 10,000 in the poorest areas of the world ${ }^{(2)}$. Congenital cataract is visible at birth or during the first decade of life. About 20,000 to 40,000 new cases of bilateral congenital cataract are diagnosed each year ${ }^{(2)}$. In Brazil, congenital cataract accounts for $12.8 \%$ of the cases of blindness in childhood ${ }^{(6-8)}$. Due to different causes, including metabolic disorders (galactosemia), infections during embryogenesis ${ }^{(5)}$, gene defects and chromosomal abnormalities ${ }^{(9)}$. Cataract may be an isolated anomaly, seen in association with another ocular developmental abnormality, or part of a multisystem syndrome, such as Down's syndrome, Wilson's disease, and myotonic dystrophy ${ }^{(10)}$.

Inherited cataracts correspond to 8 to $25 \%$ of congenital cataracts $^{(11)}$, particularly for bilateral cataract, Rahi and Dezateux ${ }^{(12)}$ found that $27 \%$ of children with bilateral isolated congenital cataract had a genetic basis compared with $2 \%$ of unilateral cases. In Brazil, some authors ${ }^{(13)}$ reported hereditary etiology in $22 \%$, intrauterine infections (rubella, toxoplasmosis, cytomegalovirus, herpes simplex, varicella, and syphilis) in 38\%, and idiopathic in $40 \%$ of the bilateral cases. Although $\mathrm{X}$-linked and autosomal recessive transmission has been observed, the most frequent mode of inheritance is autosomal dominant with a high degree of penetrance ${ }^{(14)}$. Inherited cataracts are clinically highly heterogeneous and show considerable inter and intrafamilial variability ${ }^{(15)}$.

\footnotetext{
Submitted for publication: September 5,2010

Accepted for publication: February 28, 2011

Study carried out at the Department of Ophthalmology of Irmandade da Santa Casa de Misericórdia de São Paulo.

Physician, Seção de Catarata Congênita, Departamento de Oftalmologia, Irmandade da Santa Casa de Misericórdia de São Paulo - São Paulo (SP) - Brasil.
}

Funding: No specific financial support was available for this study. Disclosure of potential conflicts of interest: A.Santana, None; M. Waiswol, None. Correspondence address: Alessandro Santana. Rua Dona Veridiana, 107/74 - São Paulo - SP 01238-010 - Brazil - E-mail: alessandro-santana@uol.com.br

Editorial Note: After completing the confidential analysis of the manuscript, ABO discloses, with his agreement, the name Dr. Paulo Pierre Filho as a reviewer. We thank his effort and expertise in participating in this process. 


\section{EMBRIOLOGY}

Lens formation is the result of a series of inductive processes. Studies of the embryology and morphogenesis of the ocular lens in animal models and humans provide an insight into the temporal and spatial disturbances that may result in the different ocular phenotypes found in inherited congenital cataract ${ }^{(16)}$. The lens forms from surface ectodermal cells overlying the optic vesicle. The lens placode appears on the optic vesicle which protrudes from the forebrain, around the $25^{\text {th }}$ day of gestation, it is a thickening of the surface ectoderm, a single layer of cuboidal cells, which invaginate into the neural ectoderm of the optic vesicle as the lens pit, becoming free from the surface by the $33^{\text {rd }}$ day. The anterior cells remain as a single layer of cuboidal epithelial cells whereas the posterior cells elongate to form primary lens fiber cells and obliterate the lumen of the vesicle. These cells are called primary lens fibers. The epithelial cells on the anterior surface of the lens vesicle then migrate laterally to the equatorial region and form the lens bow. During the third gestational month the cells in the bow region form secondary lens fibers which elongate until they encapsulate the primary lens fibers ${ }^{(14)}$.

Lens sutures appear in the second month at the anterior and posterior poles of the spherical embryonal nucleus and occur as a result of the terminal ends of the secondary lens fibers abutting each other. The anterior lens suture has an upright Y-configuration while the posterior suture has an inverted Y-configuration. The secondary lens fibers are laid down in a strictly ordered manner, such that a diffraction grating is set up with destructive interference to minimize scattering of light ${ }^{(17)}$. The secondary lens fibers are continually produced after birth and these post-natal fibers form the lens cortex. The adult lens is aneural, avascular and alymphatic. The lens contains large concentrations of proteins, known as crystallins. Up to $90 \%$ of the total soluble protein in the ocular lens is contributed by crystallins, which account for about 38\% of the wet weight of the lens. High concentrations of protein in the fiber cells lead to higher refractive indices, giving the lens its functional phenotype, namely transparency. The center of the lens is usually somewhat dehydrated and compacted and, therefore, contains higher protein concentration(18).

\section{Genes implicated in Cataractogenesis}

Congenital cataracts are also genetically heterogeneous. It is known that different mutations in the same gene can cause similar cataract patterns, while the highly variable morphologies of cataracts within some families suggest that the same mutation in a single gene can lead to different phenotypes ${ }^{(15)}$. To date, more than 25 loci and genes on different chromosomes have been associated with congenital cataract ${ }^{(19)}$. Mutations in distinct genes, which encode the main cytoplasmic proteins of human lens, have been associated with cataracts of various morphologies ${ }^{(20)}$, including genes encoding crystallins (CRYA, CRYB, and CRYG) ${ }^{(21)}$, lens specific connexins $(C \times 43, C \times 46 \text {, and } C \times 50)^{(22)}$, major intrinsic protein (MIP) or aquaporine ${ }^{(23)}$, cytoskeletal structural proteins ${ }^{(24)}$, paired-like homeodomain transcription factor 3 (PITX3) ${ }^{(25)}$, avian musculoaponeurotic fibrosarcoma (MAF) ${ }^{(26)}$, and heat shock transcription factor 4 (HSF4) ${ }^{(27)}$.

\section{Crystallin proteins}

Crystallin proteins represent more than $90 \%$ of lens soluble proteins in humans, encompassing almost 35\% of its mass, and accounting for its optical transparency and high refractive index ${ }^{(14)}$. Crystallins are subdivided into $\alpha, \beta$-, and $\Upsilon$-crystallins according to the order of their elution on gel exclusion chromatography. They are thus presumed to be inherently stable and are synthesized in the fiber cells, which lack nuclei; therefore, there is no chance of their renewal|(21)
The $\alpha$-crystallins make up $40 \%$ of human lens crystallin and comprise of two related proteins, $\alpha A$ and $\alpha B$-crystallin, with molecular weights around $20 \mathrm{kDa}$. These proteins are encoded by separate genes; respectively, CRYAA and CRYAB genes ${ }^{(22)}$. Both genes consist of three exons (coding regions) separated by two introns (non-coding regions). The $\alpha A$ is 173 amino acids long and $\alpha B$ is 175 amino acids long. The $\alpha A$ is slightly more acid than $\alpha B$. These two proteins exist in a ratio of three $(\alpha A)$ to one $(\alpha B)$ in the lens ${ }^{(21)}$. A number of reports have suggested that $\alpha A$ and $\alpha B$ are independent proteins and not subunits of the same protein. However, others observations have indicated structural and functional similarities, between these proteins, in the lens ${ }^{(28)}$. The occurrence of mutations in the CRYAA gene, for example, would have a similar effect to the $\alpha B$-crystallin function. Experimental studies have supported these findings and showed accumulation of insoluble residues and inclusion bodies of $\alpha B$-crystallin protein associated with the presence of mutations in CRYAA(29)

The $\alpha$-crystallins are related to the small heat-shock protein family, and are found in high levels in the brain, muscle, and lung. However, they are essentially a lens-specific protein. The importance of $\alpha$-crystallins in the maintenance of lens transparency is in its ability to inhibit the precipitation of denatured protein, including the $\beta$ - and $\Upsilon$-crystallins ${ }^{(28)}$. It acts as a molecular chaperone and is thereby stabilizing, and maintains the integrity of lens fiber cells and their homeostasis from various insults. Molecular chaperons facilitate the correct folding of proteins in vivo and are of extreme importance in keeping these proteins properly folded and in a functional state. Ultimately, $\alpha$-crystallins contribute to cellular architecture by interacting with and regulating the cytoskeleton ${ }^{(16)}$.

Currently, eight mutations in CRYAA gene were described ${ }^{(22}$ (Table 1). First mutation (R116C) have been associated with congenital nuclear cataract, microcornea, and microphthalmia, arginine is replaced by cysteine at position 116 . This substitution resulted in abnormal oligomerization of $\alpha$ - and $\beta$-crystallins resulting in opacification of the lens ${ }^{(29-30)}$. Second mutation is characterized for substitution of a threonine by a premature stop codon (W9X), with recessive inheritance, resulting in a truncated protein, the three affected members in this family were found to be homozygous for this substitution ${ }^{(31)}$. Others three mutations, associated with autosomal dominant inheritance were described, R21L, R49C, and G98R, this associated with a total cataract phenotype in an Indian family ${ }^{(32)}$ Recently, new mutations were related (R12C, R21W, and R116H), respectively associated with posterior polar, lamellar, and nuclear cataract ${ }^{(22)}$. Autosomal dominant isolated posterior polar cataract has been mapped to the CRYAB gene locus on 11 q22 and a deletion mutation (450delA) identified in all affected family members ${ }^{(33)}$.

The $\beta$ - and $\Upsilon$-crystallins polypeptides are recognized as members of a related $\beta / \Upsilon$-crystallin superfamily. The $\Upsilon$-crystallins are found as monomers, consisting of 173-174 residues, with a molecular mass of about $20 \mathrm{kDa}^{(21)}$. The $\beta$-crystallins are polymeric structures comprised of a family of seven subunits of 22-33 kDa. The $\beta$-crystallin family consists of four acidic and three basic forms depending on the isoelectric point and the terminal extensions. The basic $(\beta \mathrm{B})$ members of this group contain C-terminal extensions, while the acidic members $(\beta A)$ do not have this extension ${ }^{(34)}$.

The $\beta / \Upsilon$-crystallins proteins are proteins that share a "Greek Key" (GK) motif unit base. They contain two domains, an N-terminal domain and a C-terminal domain as the core. Each domain contains two GK motifs; each GK motif is composed of four antiparallel $\beta$-strands. The two domains are connected by a distinct connecting peptide ${ }^{(21)}$

The $\beta$-crystallins are divided into seven subgroups, three basic ( $\beta B 1, \beta B 2$, and $\beta B 3$-crystallins) located on chromosome $22 q 11$ and four acidic forms; $\beta$ A1/A3-crystallin located on chromosome 17q11; $\beta A 2$-crystallin located on chromosome2q33, and $\beta A 4$-crystallin located on chromosome $22 q^{1} 1^{(10)}$. Two mutations in CRYBA1 gene, that encode the $\beta \mathrm{A} 1$-crystallin protein, were identified (IVS3 $+1 \mathrm{G} \rightarrow \mathrm{A}$, 
and c.271-273delGGA). The IVS3 + 1G $\rightarrow$ A mutation has been described in two unrelated families and cause different cataract phenotypes; lamellar, and sutural cataract in an Indian family, and nuclear cataract in an Australian family ${ }^{(34)}$. To the CRYBB2 gene three mutations were identified (Table 1), Q155X, D128V, and W151C, the first mutation is predicted to remove the final 51 amino acids, resulting in an unstable molecule ${ }^{(35)}$.

Biochemically, the $\Upsilon$-crystallins are characterized as monomers with a molecular mass of $21 \mathrm{kDa}$, and 173-174 amino acid residues long. Mutations associated with a clinical phenotype have been found up to now only in CRYGC and CRYGD genes (located on chromosome 2q), which encode respectively, the $\mathrm{rC}$ and $\mathrm{rD}$-crystallin proteins ${ }^{(21)}$. Although the resulting phenotypes can vary significantly, mutations in $\Upsilon$-crystallins tend to produce nuclear or lamellar cataracts, consistent with their high level of expression in the lens nucleus. The $\Upsilon$-crystallins encoding genes (CRYG genes) in all mammals consist of three exons: the first one codes only three amino acids, and the subsequent two are responsible for two Greek Key motifs each.

An increasing number of mutations in the CRYG genes have been described in association with human congenital cataract ${ }^{(32)}$. To date, five mutations in the CRYGC gene (T5P, 225-226insGCGGC, C109X, W157X, and R168W) were reported ${ }^{(36)}$. Of the missense mutations, T5P is associated with nuclear cataract and R168W have been reported to cause lamellar and nuclear cataract in Mexican and Indian families ${ }^{(37)}$. Others ten mutations in the CRYGD gene have been described ${ }^{(11)}$ (Table 2). Hansen et al. ${ }^{(22)}$ related that the mechanisms through which protein abnormalities cause loss of lens transparency are still speculative. Functional studies on the mutant CRYGD gene have shown that the R36S and R58H not alter the protein fold, but rather to alter the surface characteristics of the protein, turned out them less soluble and more prone to crystallization. In the R14C mutation the protein also maintains a normal protein fold, but is susceptible to aggregation. Consequently, the crystallins do not need to undergo denaturation or other major changes in their protein folds to cause cataracts ${ }^{(20)}$.

\section{Connexin proteins}

Connexin proteins are constituents of gap-junctions, especially important for nutrition and intercellular communication in the avascular lens. They mediate the intercellular transportation of small biomolecules, including ions, nutrients, and metabolites. These functions of connexins play an important role in lens metabolic homeostasis and maintenance of transparency of fibers within the ocular lens. Because of its unique function and anatomy, the mammalian lens is critically dependent on the proper functioning

Table 1. Mutations identified in CRYAA, CRYAB, CRYBA1, and CRYBB2 genes in association with congenital cataract

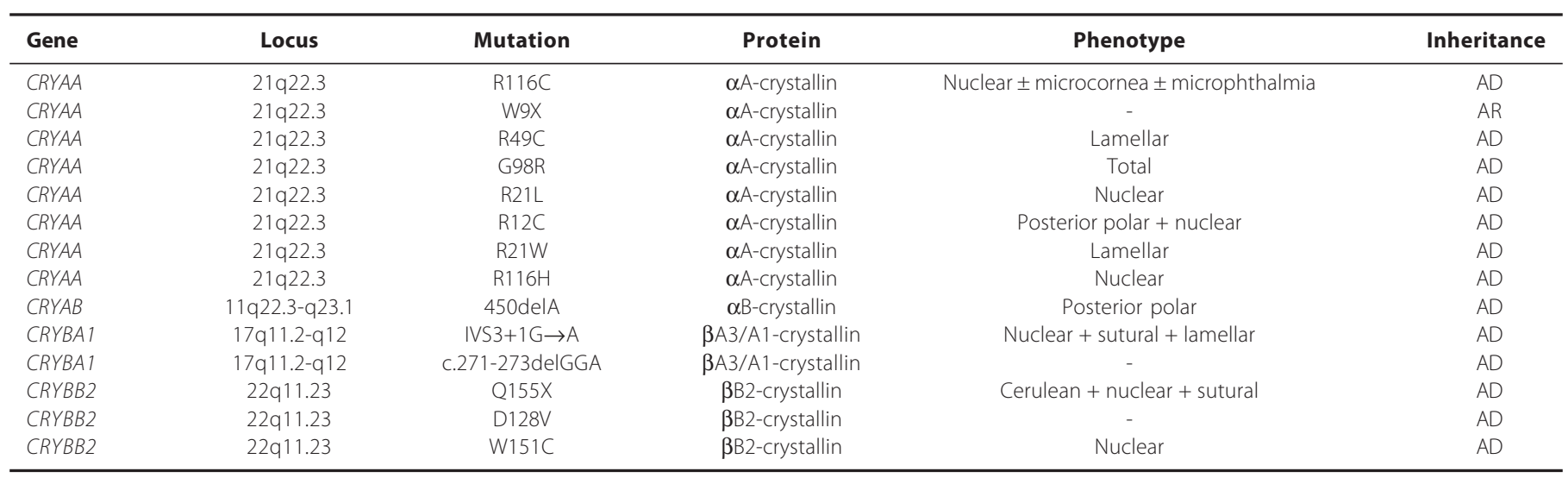

$\mathrm{R}=$ arginine; $\mathrm{C}=$ cysteine; $\mathrm{W}=$ tryptophan; $\mathrm{X}=$ stop codon; $\mathrm{G}=$ glycine; $\mathrm{L}=$ leucine; $\mathrm{H}=$ histidine; $\mathrm{Q}=$ glutamine; $\mathrm{D}=$ aspartic acid $\mathrm{V}=$ valine; del= deletion; $\mathrm{AD}=$ autosomal dominant; $\mathrm{AR}=$ autosomal recessive

Table 2. Mutations identified in CRYGC and CRYGD genes in association with congenital cataract

\begin{tabular}{|c|c|c|c|c|c|}
\hline Gene & Locus & Mutation & Protein & Phenotype & Inheritance \\
\hline CRYGC & $2 q 33-q 35$ & T5P & rC-crystallin & Lamellar pulverulent & $A D$ \\
\hline CRYGC & $2 q 33-q 35$ & 225-226insGCGGC & rC-crystallin & Nuclear pulverulent & $A D$ \\
\hline CRYGC & $2 q 33-q 35$ & R168W & rC-crystallin & Lamellar & $A D$ \\
\hline CRYGC & $2 q 33-q 35$ & C109X & rC-crystallin & Nuclear & $A D$ \\
\hline CRYGC & $2 q 33-q 35$ & W157X & rC-crystallin & Nuclear + microcornea & $A D$ \\
\hline CRYGD & $2 q 33-q 35$ & $\mathrm{R} 58 \mathrm{H}$ & rD-crystallin & Lamellar & $A D$ \\
\hline CRYGD & $2 q 33-q 35$ & $\mathrm{R} 14 \mathrm{C}$ & rD-crystallin & Punctate juvenile progressive & $A D$ \\
\hline CRYGD & $2 q 33-q 35$ & Y134X & rD-crystallin & Total & $A D$ \\
\hline CRYGD & $2 q 33-q 35$ & E107A & rD-crystallin & Nuclear & $A D$ \\
\hline CRYGD & $2 q 33-q 35$ & W156X & rD-crystallin & Nuclear & $A D$ \\
\hline CRYGD & $2 q 33-q 35$ & P23T & rD-crystallin & Lamellar & $A D$ \\
\hline$C R Y G D$ & $2 q 33-q 35$ & R36S & rD-crystallin & Coraliform & $A D$ \\
\hline$C R Y G D$ & $2 q 33-q 35$ & Y56X & rD-crystallin & Nuclear & $A D$ \\
\hline CRYGD & $2 q 33-q 35$ & G61C & rD-crystallin & Coralliform & $A D$ \\
\hline CRYGD & $2 q 33-q 35$ & R140X & rD-crystallin & Nuclear & $A D$ \\
\hline
\end{tabular}

$\mathrm{T}=$ threonine; $\mathrm{P}=$ proline; ins= insertion; $\mathrm{R}=$ arginine; $\mathrm{W}=$ tryptophan; $\mathrm{H}=$ histidine; $\mathrm{C}=$ cysteine; $\mathrm{Y}=$ tyrosine; $\mathrm{X}=$ stop codon; $\mathrm{E}=$ glutamic acid; $\mathrm{A}=$ alanine; $\mathrm{S}=$ serine; $\mathrm{G}=$ glycine; $\mathrm{AD}=$ autosomal dominant 
of gap-junction proteins ${ }^{(16)}$. Each gap-junction channel is composed of two hemi-channels, or connexons, which dock in the extracellular space between adjacent cells, and each connexon is comprised of six integral transmembrane protein subunits known as connexins ${ }^{(38)}$. Connexins are a multigene family consisting of $>20$ members, three of which are expressed in the lens $(C \times 43, C \times 46$, and $C \times 50)$. The lens epithelial cells show a predominant expression of connexin 43 (Cx43). During differentiation into fibers, $\mathrm{C} \times 43$ expression is down regulated and replaced by connexin 46 (Cx46) and connexin 50 (Cx50) ${ }^{(14)}$.

Mutations of specific connexin genes have been associated with several disease including genetic deafness, skin disease, peripheral neuropathies, heart defects and cataracts. Mutations in both $C \times 46$ and C $\times 50$ genes have produced phenotypically similar autosomal dominant lamellar pulverulent cataracts. Cx50 on chromosome 1q22 is constituted of two exons, which resulted in a protein with 433 residues. Shiels et al. ${ }^{(39)}$ reported a missense mutation in codon 88 of the Cx50 gene, leading to the substitution of proline by serine (P88S), associated with autosomal dominant lamellar pulverulent cataract in an English family. To date, there are other thirteen mutations on $\mathrm{C} \times 50$ found in different hereditary cataract pedigrees; they are V44E, V64G, V79L, P88Q, Q48K, P189S, R198Q, R23T, W45S, D47N, D47Y, S276F, and I274M. This last mutation, located in the cytoplasmic $\mathrm{COOH}$-terminus, was found in a Russian family in 2001, and it was related to a lamellar pulverulent cataract $^{(40)}$. $C \times 46$ consists of a single exon encoding a 435 amino acid protein in humans and is localized on chromosome 13 (13q11-q13). Fourteen mutations in Cx46 gene involving the different domains so far been reported to be associated with autosomal dominant congenital cataract in humans (Table 3 ).

\section{Major intrinsic protein (MIP) or Aquaporine-O (AQPO)}

MIP is an integral membrane protein member of the aquaporine family of water transporters and small selected molecular of plasmatic membrane. It is the most highly expressed membrane protein in the lens, almost $80 \%$ of transport protein. Lamellar, cortical and polymorphic cataracts have been associated with missense mutations in the AQPO gene. Recently, two mutations have been related; the first mutation, T138R, is associated with a progressive congenita lamellar and polar cataract, and the second E134G is associated with lamellar cataract(23). Both of these mutations appear to act by interfering with normal trafficking of AQPO to the plasma membrane and thus with water channel activity (Table 3).

\section{Cytoskeletal proteins}

The architecture of lens cells is resulted of the interaction of the cytoskeleton, crystallin proteins, and cytoplasm. The cytoskeletal is a network of varied cytoplasmatic proteins which are involved in providing structural support, cell motility, and determination and maintenance of cell volume and shape. Lens cells present three different filaments, which are differentiated by diameter, types of subunits, and molecular organization: microfilaments, microtubes, and intermediate filaments ${ }^{(16)}$. Microfilaments and microtubes facilitate changes of ions, while intermediate filaments aid lens cells in overcomping physical stresses including lens accommodation and changes of temperature ${ }^{(41)}$.

Beaded Filament Structural Proteins (BFSP) are a type of intermediate filament unique eye-lens-specific cytoskeletal structure, which contains two core components of BFSP1(also called filensin)

Table 3. Mutations identified in $C_{x} 46, C_{x 50}$, and MIP genes in association with congenital cataract

\begin{tabular}{|c|c|c|c|c|c|}
\hline Gene & Locus & Mutation & Protein & Phenotype & Inheritance \\
\hline$C \times 46$ & $13 q 11-q 13$ & N63S & Connexin 46 & Nuclear pulverulent & $A D$ \\
\hline$C \times 46$ & $13 q 11-q 13$ & 1136-1137insC & Connexin 46 & Nuclear pulverulent & $A D$ \\
\hline$C \times 46$ & $13 q 11-q 13$ & P187L & Connexin 46 & Nuclear pulverulent & $A D$ \\
\hline$C \times 46$ & $13 q_{111-q 13}$ & D3Y & Connexin 46 & Nuclear pulverulent & $A D$ \\
\hline$C \times 46$ & $13 q 11-q 13$ & L11S & Connexin 46 & Nuclear pulverulent & $A D$ \\
\hline$C \times 46$ & $13 q 11-q 13$ & F32L & Connexin 46 & Nuclear pulverulent & $A D$ \\
\hline$C \times 46$ & $13 q_{11}-q_{13}$ & P59L & Connexin 46 & Nuclear pulverulent & $A D$ \\
\hline$C \times 46$ & $13 q_{111-q 13}$ & R76G & Connexin 46 & Nuclear pulverulent & $A D$ \\
\hline$C \times 46$ & $13 q 11-q 13$ & $\mathrm{R} 76 \mathrm{H}$ & Connexin 46 & Nuclear pulverulent & $A D$ \\
\hline$C \times 46$ & $13 q 11-q 13$ & M1I & Connexin 46 & - & $A D$ \\
\hline$C \times 46$ & $13 q_{111-q 13}$ & V28M & Connexin 46 & Variable & $A D$ \\
\hline$C \times 46$ & $13 q 11-q 13$ & R33L & Connexin 46 & Granular & $A D$ \\
\hline$C \times 46$ & $13 q 11-q 13$ & $\mathrm{~T} 87 \mathrm{M}$ & Connexin 46 & - & $A D$ \\
\hline$C \times 46$ & $13 q 11-q 13$ & N188T & Connexin 46 & Nuclear pulverulent & $A D$ \\
\hline$C \times 50$ & $1 \mathrm{q} 21.1$ & P88S & Connexin 50 & Lamellar pulverulent & $A D$ \\
\hline$C \times 50$ & $1 \mathrm{q} 21.1$ & P88Q & Connexin 50 & Nuclear pulverulent & $A D$ \\
\hline$C \times 50$ & $1 \mathrm{q} 21.1$ & Q48K & Connexin 50 & Nuclear pulverulent & $A D$ \\
\hline $6 \times 50$ & $1 q 21.1$ & V44E & Connexin 50 & Total & $A D$ \\
\hline$C \times 50$ & $1 \mathrm{q} 21.1$ & V64G & Connexin 50 & Nuclear & $A D$ \\
\hline$C \times 50$ & $1 q 21.1$ & V79L & Connexin 50 & Sutural & $A D$ \\
\hline$C \times 50$ & $1 \mathrm{q} 21.1$ & P189S & Connexin 50 & Cortical & $A D$ \\
\hline$C \times 50$ & $1 \mathrm{q} 21.1$ & R198Q & Connexin 50 & Subcapsular & $A D$ \\
\hline$C \times 50$ & $1 q 21.1$ & $1247 \mathrm{M}$ & Connexin 50 & Lamellar pulverulent & $A D$ \\
\hline$C \times 50$ & $1 q 21.1$ & $\mathrm{R} 23 \mathrm{~T}$ & Connexin 50 & Progressive nuclear & $A D$ \\
\hline $6 \times 50$ & $1 q 21.1$ & W45S & Connexin 50 & Jellyfish-like + microcornea & $A D$ \\
\hline$C \times 50$ & $1 \mathrm{q} 21.1$ & D47N & Connexin 50 & Nuclear pulverulent & $A D$ \\
\hline$C \times 50$ & $1 q 21.1$ & D47Y & Connexin 50 & Nuclear & $A D$ \\
\hline$C \times 50$ & $1 q 21.1$ & $\mathrm{~S} 276 \mathrm{~F}$ & Connexin 50 & Nuclear pulverulent & $A D$ \\
\hline MIP & $12 q 12$ & $\mathrm{~T} 138 \mathrm{R}$ & MP26 & Progressive lamellar + posterior polar & $A D$ \\
\hline MIP & $12 q 12$ & E134G & MP26 & Lamellar & $A D$ \\
\hline
\end{tabular}

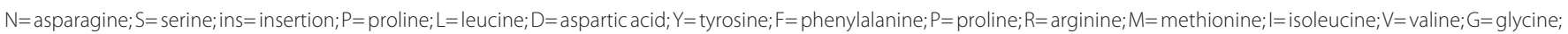
$\mathrm{H}=$ histidine; $\mathrm{T}=$ threonine; $\mathrm{Q}=$ glutamine; $\mathrm{K}=$ lysine; $\mathrm{E}=$ glutamic acid; $\mathrm{W}=$ tryptophan; $\mathrm{AD}=$ autosomal dominant 
and BFSP2 (also called CP49), highly divergent intermediate filament proteins that combine in the presence of $\alpha$-crystallin to form the appropriate beaded structure. The gene encoding BFSP2 are located on human chromosome 3q21. Actually, two mutations in BFSP2 gene have been demonstrated with the occurrence of congenital cataracts. The first mutation (R278W) had associated with juvenile-onset cataract ${ }^{(41)}$, while the second mutation (delE233), had identified in a large family, which affected members had congenital nuclear, sutural, and cortical cataracts that varied in severity among different individuals (Table 4).

\section{Developmental regulators}

Embryonic lens development is predicted by spatial and temporal interactions of several genes and their products. The genes involved in this complex process encoding growth factors and transcription factors. These proteins regulate transcription of a number of tissue-specific genes during differentiation, and play a crucial role in lens plan specification. Depending on the nature of the genetic defect involved, mutations in genes that define development can result in multiple abnormalities of the eye, particularly congenital cataract. Mutations in transcription factors genes have been implicated in anterior segment dysgenesis, but only three: PITX3, MAF, and HSF4, have been associated with isolated cataract (Table 4).

Mutations PITX3 gene result predominantly in autosomal dominant congenital cataract associated with dysgenesis of the anterior segment, including corneal opacity, iris adhesions, microcornea, and microphthalmia. Two mutations had been described, a 17-bp insertion of the coding sequence (656-657ins17bp), resulting in a frame shift, and a $\mathrm{G} \rightarrow \mathrm{A}$ transition in exon 2 of PITX3 gene, resulting in a serine to asparagine substitution at codon $13(\mathrm{~S} 13 \mathrm{~N})^{(25)}$. Jamieson et al. ${ }^{(42)}$ related a R288P substitution within the MAF gene on chromosome $16 q 22-q 23$ in a family with autosomal dominant juvenile pulverulent cataract, iris coloboma, and microcornea. In addition to MAF gene, another missense mutation (K297R) was found in twelve affected members in an Indian family, associated with autosomal dominant cerulean cataract and microcornea ${ }^{(26)}$. HSF4 gene regulates the expression of heat-shock proteins (HSPs), which may be important components of lens development. Currently, six mutations of this gene had been associated with congenital cataracts, which resulted in lamellar progressive and nuclear phenotype ${ }^{(27)}$.

\section{Crystallin gene mutations associated With CONGENITAL CATARACT IN BRAZILIAN FAMILIES}

A recent study in Brazil, Santana et al. ${ }^{(43)}$ have demonstrated a novel nonsense mutation (Y56X) in the CRYGD gene and a pre- viously reported missense mutation (R12C) in the CRYAA gene associated with nuclear congenital cataract in Brazilian families. Additionally, they also observed a new polymorphism (S119S) in the CRYGC gene. In this study, eleven families with autosomal dominant childhood cataracts were identified, seven families presenting with nuclear phenotype and remaining families with lamellar phenotype. A total of thirty-four affected members and forty-four unaffected members were evaluated. DNA sequencing analysis of CRYGD gene showed a novel heterozygous nonsense mutation $($ TAC $\rightarrow$ TAG) within the second exon (Figure 1). Cataract was most likely caused by this point mutation that led to the replacement of a tyrosine by a premature stop codon at position 56 (Y56X). The congenital bilateral nuclear cataract in another family was associated with a mutation in CRYAA, a point mutation in exon 1 (CGC $\rightarrow$ TGC), which led to the replacement of an arginine at position 12 for a cysteine (R12C) (Figure 2). A variety of sequence variations referred as single nucleotide polymorphisms was observed in the probands for the CRYAA, CRYGC and CRYGD genes. None of these sequences changed in the coding regions led to amino acids alterations. Three known polymorphisms were observed in the sequencing analysis: D2D (rs872331) polymorphism (GAC $\rightarrow$ GAT) in the CRYAA gene (exon 1), observed in ten probands, Y17Y (rs2242074) polymorphism (TAT $\rightarrow$ TAC) observed in the CRYGD gene (exon 2), in seven probands, and R95R (rs2305430) polymorphism (AGA $\rightarrow$ AGG) in the CRYGD gene (exon 3), in nine probands. A new polymorphism in the third exon of the CRYGC gene (S119S) was observed in a family (Figure 3).

\section{CONCLUSION}

The study of genes related to congenital cataract and knowledge about the molecular mechanisms of their origin could in the near future, be extended also to the age-related cataracts, which remains the leading cause of blindness worldwide. The accumulation of information about the physiology of the lens and the factors associated with the formation of senile cataracts acquired through genetic studies of congenital hereditary form, allow the emergence of new treatments and techniques to prevent this type of cataract. The age-related cataract has been considered multi-factorial with multiple genes and environmental factors influencing the phenotype. Increasing age is the most important risk factor for agerelated cataract, as the opacities result from the cumulative damage of environmental insult to proteins and cells of the lens. Photochemical insult, producing hydrogen peroxide, superoxide and hydroxyl radical induces damage to the lens epithelial cell DNA thus triggering a sequence of events leading to cataract. A

Table 4. Mutations identified in BFSP2, PITX3, MAF, and HSF4 genes in association with congenital cataract

\begin{tabular}{|c|c|c|c|c|c|}
\hline Gene & Locus & Mutation & Protein & Phenotype & Inheritance \\
\hline BFSP2 & $3 q 21.2-q 22.3$ & $\mathrm{R} 287 \mathrm{~W}$ & BFSP2 & Nuclear + juvenile sutural & $A D$ \\
\hline BFSP2 & $3 q 21.2-q 22.3$ & delE233 & BFSP2 & Cortical + nuclear + sutural & $A D$ \\
\hline PITX3 & 10q24-q25 & $\mathrm{S} 13 \mathrm{~N}$ & PITX3 & Total & $A D$ \\
\hline MAF & $16 q 22-q 23$ & R288P & MAF & Pulverulent + microcornea + iris coloboma & $A D$ \\
\hline MAF & $16 q 22-q 23$ & K297R & MAF & Cerulean + microcornea & $A D$ \\
\hline HSF4 & $16 q 22$ & A19D & HSF4 & Lamellar & $A D$ \\
\hline HSF4 & $16 q 22$ & L114P & HSF4 & Lamellar & $A D$ \\
\hline HSF4 & $16 \mathrm{q} 22$ & R119C & HSF4 & Lamellar & $A D$ \\
\hline HSF4 & $16 \mathrm{q} 22$ & R175P & HSF4 & Lamellar & $A R$ \\
\hline
\end{tabular}

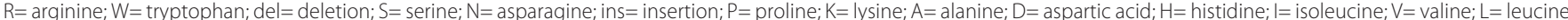
$\mathrm{C}=$ cysteine; $\mathrm{AD}=$ autosomal dominant; $\mathrm{AR}=$ autosomal recessive 
markedly inhibition of the DNA synthesis and repair has also been observed in experimental studies. Oxidative stress has been associated expression changes (increase or decrease) of genes in the lens epithelium. Known genetic and environmental factors might direct the application of preventive measures, such as identifi- cation of risk groups, change of lifestyle, control of serum glucose, decreased alcohol consumption, smoking and exposure to ultraviolet rays. In addition, the prophylactic use of therapeutic agents (antioxidant, vitamin supplement, carotenoids), diet therapy and gene therapy will prevent or delay opacification.
A

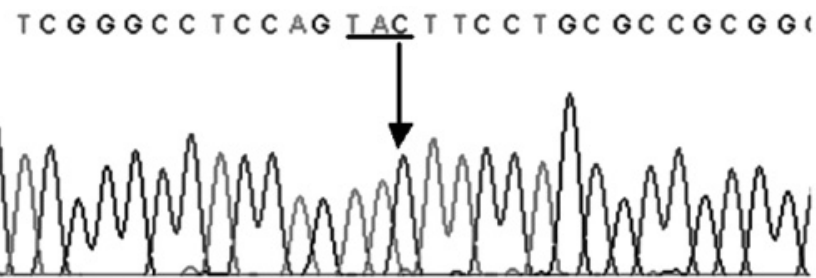

TCG GGC $\underline{\text { CTC }} \underline{\text { CAG }} \frac{\text { TAC ITC }}{Y} \underline{\text { CTG }} \underline{\text { CGC }} \underline{\text { CGC }}$

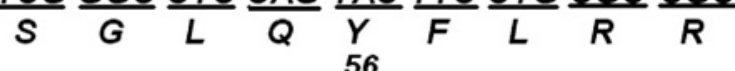

B

TCGGGCCTCCAGIANTTCCTGCGCCGCGGI

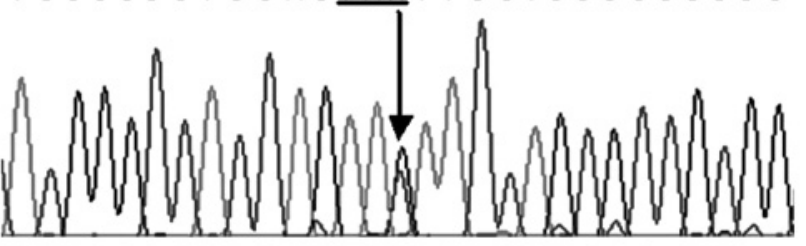

TCG GGC CTC CAG TAN TTC CTG CGC CGC

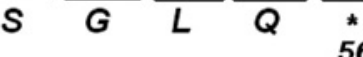

$\mathrm{S}=$ serine $; \mathrm{G}=$ glycine $\mathrm{L}=$ leucine; $\mathrm{Q}=$ glutamine $\mathrm{Y}=$ tyrosine; $\mathrm{F}=$ phenylalanine; $\mathrm{R}=$ arginine

Figure 1. A) The DNA sequencing chromatograms of the PCR product encompasses exon 2 of $C R Y G D$ gene ( $\left.5^{\prime} \rightarrow 3^{\prime}\right)$ of an unaffected individual; B) The DNA sequencing chromatograms of the PCR product encompassing exon 2 of $C R Y G D$ gene shows a heterozygous TAC $\rightarrow$ TAG transition that replaced a tyrosine (Y) by a premature stop codon (X) at amino acid 56 (Y56X) in affected individual. Modified from: Santana A. Avaliação estrutural dos genes CRYAA, CRYGC e CRYGD em pacientes portadores de catarata congênita autossômica dominante [doutorado]. São Paulo: Santa Casa de Misericórdia de São Paulo; 2009.

A

ACCCCTGGTTCAAGCGCACCCTGGGGCCC

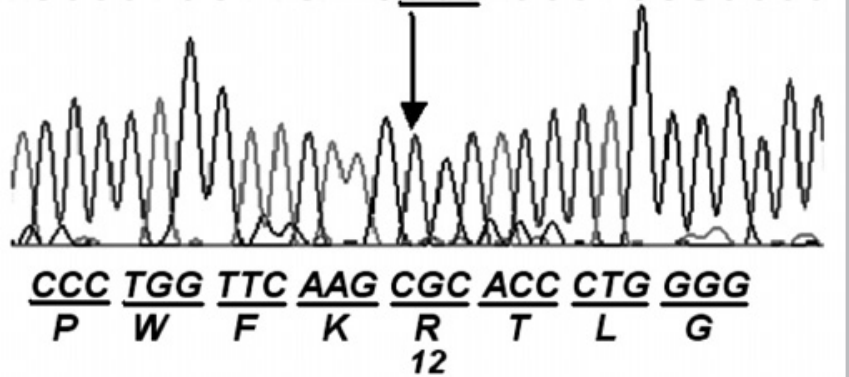
I C C C TGGT T CAAGNGCACCCTGGGGCCC

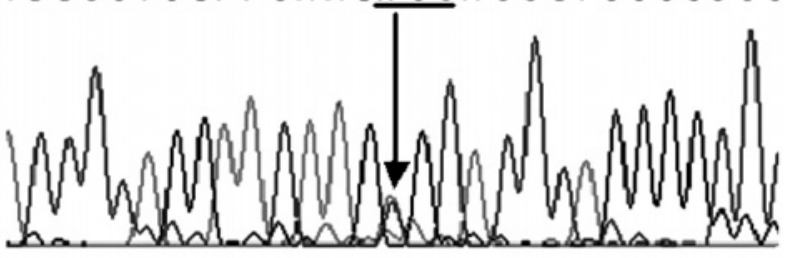

CCC TGG ITC $\underline{\text { AAG }} \underline{\text { NGC }} \underline{\text { ACC }} \underline{\text { CTG }} \underline{\text { GGG }}$

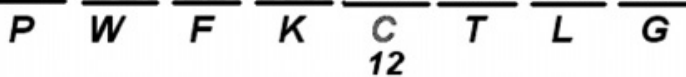

$\mathrm{P}=$ proline; $\mathrm{W}=$ tryptophan; $\mathrm{F}=$ phenylalanine; $\mathrm{K}=$ lysine; $\mathrm{T}=$ threonine; $\mathrm{L}=$ leucine; $\mathrm{G}=$ glycine

Figure 2. A) Direct sequencing of the PCR product encompasses exon 1 of $C R Y A A$ gene $\left(5^{\prime} \rightarrow 3^{\prime}\right)$ of an unaffected individual; B) Direct sequencing of the PCR product encompassing exon 1 of CRYAA gene of an affected individual shows a heterozygous CGC $\rightarrow$ TGC transition that replaced arginine (R) by cysteine (C) at amino acid 12 (R12C). Modified from: Santana A. Avaliação estrutural dos genes CRYAA, CRYGC e CRYGD em pacientes portadores de catarata congênita autossômica dominante [doutorado]. São Paulo: Santa Casa de Misericórdia de São Paulo; 2009.

A

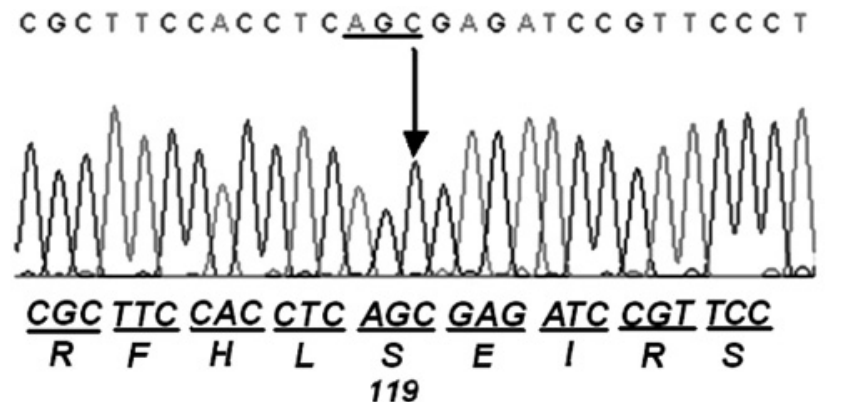

B

C GCT TCCACCTC

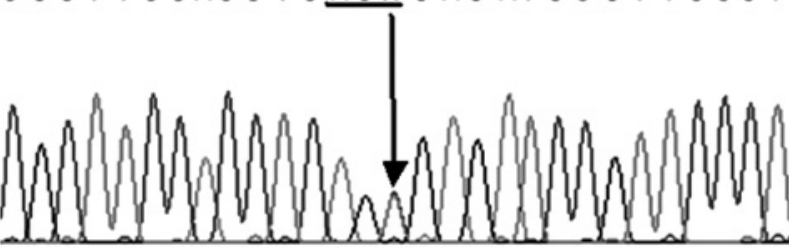

$\frac{C G C}{R} \frac{T T C}{F} \frac{C A C}{C} \frac{C T C}{L} \frac{A G N}{S} \underline{G A G} \frac{A T C}{C} \frac{C G T}{R} \frac{T C C}{S}$

$\mathrm{R}=$ arginine; $\mathrm{F}=$ phenylalanine; $\mathrm{H}=$ histidine; $\mathrm{L}=$ leucine; $\mathrm{S}=$ serine; $\mathrm{E}=$ glutamic acid $\mathrm{I}=$ isoleucine

Figure 3. A) The DNA sequencing chromatograms of the PCR product encompasses exon 3 of $C R Y G C$ gene $\left(5^{\prime} \rightarrow 3^{\prime}\right)$ shows homozygous for allele $C$; $B$ ) The DNA sequencing chromatograms of the PCR product encompassing exon 3 of $C R Y G C$ gene shows a heterozygous polymorphism $A G C \rightarrow A G T$ transition, which does not result in the substitution of serine (S) at amino acid 119 (S119S). Modified from: Santana A. Avaliação estrutural dos genes CRYAA, CRYGC e CRYGD em pacientes portadores de catarata congênita autossômica dominante [doutorado]. São Paulo: Santa Casa de Misericórdia de São Paulo; 2009. 


\section{REFERENCES}

1. Foster A, Gilbert C, Rahi J. Epidemiology of cataract in childhood: a global perspective. Cataract Refract Surg. 1997;23 Suppl 1:601-4.

2. Apple DJ, Ram J, Foster A, Peng Q. Elimination of cataract blindness: a global perspective entering the new millennium. Surv Ophthalmol. 2000;45 Suppl 1:S1-196.

3. Gilbert C, Foster A. Childhood blindness in the context of VISION 2020 - The right to sight. Bull World Health Organ. 2001;79(3):227-32.

4. Foster A. Worldwide blindness, increasing but avoidable. Semin Ophthalmol. 1993; 8(3):166-70.

5. Rahi JS, Scripathi S, Gilbert C, Foster A. Childhood blindness in India: causes in 1318 blind school students in nine states. Eye (Lond). 1995;9(5):545-50.

6. Tartarella MB, Kawakami LT, Scarpi MJ, Hayashi S. Aspectos cirúrgicos em catarata congênita. Arq Bras Oftalmol. 1995;58(1):24-8.

7. Carvalho KM, Minguini N, Moreira Filho DC, Kara-José N. Characteristics of a pediatric lowvision population. J Pediatr Ophthalmol Strabismus. 1998;35(3):162-5.

8. Haddad MA, Lobato FJ, Sampaio MW, Kara-José N. Pediatric and adolescent population with visual impairment: study of 385 cases. Clinics (São Paulo). 2006;61(3):239-46.

9. Eckstein M, Vijayalakshmi P, Killerdar M, Gilbert C, Foster A. Aetiology of childhood cataract in south India. Br J Ophthalmol. 1996;80(7):628-32.

10. He W, Li S. Congenital cataracts: gene mapping. Hum Genet. 2000;106(1):1-13.

11. Messina-Baas OM, Gonzalez-Huerta LM, Cuevas-Covarrubias SA. Two affected siblings with nuclear cataract associated with a novel missense mutation in the CRYGD gene. Mo Vis. 2006;12:995-1000.

12. Rahi JS, Dezateux C. National cross sectional study of detection of congenital and infantile cataract in the United Kingdom: role of childhood screening and surveillance. The British Congenital Cataract Interest Group. BMJ. 1999;318(7180):362-5.

13. Oliveira ML, Di Giovanni ME, Porfírio Neto Jr, Tartarella MB. Catarata congênita: aspectos diagnósticos, clínicos e cirúrgicos em pacientes submetidos à lensectomia. Arq Bras Oftalmol. 2004;67(6):921-6.

14. Beby F, Morle L, Michon L, Bozon M, Edery P, Burillon C, et al. [The genetics of hereditary cataract]. J Fr Ophtalmol. 2003;26(4):400-8. French.

15. Gill D, Klose R, Munier FL, McFadden M, Priston M, Billingsley G, et al. Genetic heterogeneity of the Coppock-like cataract: a mutation in CRYBB2 on chromosome 22q11.2. Invest Ophthalmol Vis Sci. 2000;41(1):159-65.

16. Reddy MA, Francis PJ, Berry V, Bhattacharya S, Moore AT. Molecular genetic basis of inherited cataract and associated phenotypes. Surv Ophthalmol. 2004(3);49:300-15.

17. Bettelheim FA, Chylack LT Jr. Light scattering of whole excised human cataractous lenses. Relationships between different light scattering parameters. Exp Eye Res. 1985:41(1):19-30

18. Kannabiran C, Balasubramanian D. Molecular genetics of cataract. Indian J Ophthalmol. 2000;48(1):5-13.

19. Guleria K, Sperling K, Singh D, Varon R, Singh JR, Vanita V. A novel mutation in the connexin 46 (GJA3) gene associated with autosomal dominant congenital cataract in an Indian family. Mol Vis. 2007:13:1657-65

20. Hejtmamcik JF, Smaoui N. Molecular genetics of cataract. Dev Ophthalmol. 2003;37:67-82.

21. Bhat SP. Crystallins, genes and cataract. Prog Drug Res. 2003;60:205-63.

22. Hansen L, Yao W, Eiberg H, Kjaer KW, Baggesen K, Hejtmancik JF, et al. Genetic heterogeneity in microcornea-cataract: five novel mutations in CRYAA, CRYGD, and GJA8. Invest Ophthalmol Vis Sci. 2007;48(9):3937-44.

23. Berry V, Francis P, Kaushal S, Moore A, Bhattacharya S. Missense mutations in MIP underlie autosomal dominant "polymorphic" and lamellar cataracts linked to 12q. Nat Genet. 2000;25(1):15-7

24. Jakobs PM, Hess JF, FitzGerald PG, Kramer P, Weleber RG, Litt M. Autosomal-dominant congenital cataract associated with deletion mutation in the human beaded filament protein gene BFSP2. Am J Hum Genet. 2000;66(4):1432-6.
25. Semina EV, Ferrell RE, Mintz-Hittner HA, Bitoun P, Alward WL, Reiter RS, et al. A novel homeobox gene PITX3 is mutated in families with autosomal-dominant cataract and ASMD. Nat Genet. 1998;19(2):167-70.

26. Vanita V, Singh D, Robinson PN, Sperling K, Singh JR. A novel mutation in the DNAbinding domain of MAF at 16q23-1 associated with autosomal dominant "cerulean cataract" in an Indian family. Am J Med Genet A. 2006;140(6):558-66.

27. Forshew T, Johnson CA, Khaliq S, Pasha S, Willis C, Abbasi R, et al. Locus heterogeneity in autosomal recessive congenital cataracts: linkage to $9 q$ and germline HSF4 mutations. Hum Genet. 2005;117(5):452-9.

28. Augusteyn RC. Alpha-crystallin: a review of its structure and function. Clin Exp Optom 2004;87(6):356-66.

29. Brady JP, Garland D, Duglas-Tabor Y, Robison WG Jr, Groome A, Wawrousek EF. Targed disruption of the mouse alpha A-crystallin gene induces cataract and cytoplasmic inclusion bodies containing the small heat-shock protein alpha B-crystallin. Proc Nat Acad Sci USA. 1997:94(3):884-9.

30. Bera S, Abraham EC. The alphaA-crystallin R116C mutant has a higher affinity for forming heteroaggregates with alphaB-crystallin. Biochemistry. 2002;41(1):297-305.

31. Pras E, Frydman M, Levy-Nissenbaum E, Bakhan T, Raz J, Assia El, et al. A nonsense mutation (W9X) in CRYAA causes autosomal recessive cataract in an inbred Jewish Persian family. Invest Ophthalmol Vis Sci. 2000;41(11):3511-5.

32. Santhiya ST, Soker T, Klopp N, Illig T, Prakash MV, Selvaraj B, et al. Identification of a novel, putative cataract - causing allele in CRYAA (G98R) in an Indian family. Mol Vis. 2006:12:768-73.

33. Berry V, Francis $P$, Reddy MA, Collyer D, Vithana E, Mackay L, et al. Alpha-B crystalline gene (CRYAB) mutation causes dominant congenital posterior polar cataract in humans. Am J Hum Genet. 2001;69(5):1141-5.

34. Reddy MA, Bateman OA, Chakarova C, Ferris J, Berry V, Lomas E, et al. Characterization of the G91 del CRYBA1/3 crystallin protein: a cause of human inherited cataract. Hum Mol Genet. 2004;13(9):945-53.

35. Santhiya ST, Manisastry SM, Rawlley D, Malathi R, Anishetty S, Gopinath PM, et al. Mutation analysis of the congenital cataracts in Indian families: identification of SNPs and a new causative allele in CRYBB2 gene. Invest Ophthalmol Vis Sci. 2004;45(10):3599-607.

36. Santhiya ST, Shyam Manohar M, Rawlley D, Vijayalaskshmi P, Namperumalsamy P, Gopinath PM, et al. Novel mutations in the gamma-crystallin genes cause autosoma dominant congenital cataracts. J Med Genet. 2002;39(5):352-8. Comment on: J Med Genet. 2000;37(7):481-8.

37. Fu L, Liang JJ. Conformational change and destabilization of cataract gammaC-crystallin T5P mutant. FEBS Lett. 2002;513(2-3):213-6.

38. Goodenough DA, Goliger JA, Paul DL. Connexins, connéxons, and intercellular communication. Annu Rev Biochem. 1996;65:475-502.

39. Shiels A, Mackay D, lonides A, Berry V, Moore A, Bhattacharya S. A missense mutation in the human connexion 50 gene (GJA8) underlies autosomal dominant "zonular pulverulent" cataract, on chromosome 1q. Am J Hum Genet. 1998;62(3):526-32.

40. Polyakov AV, Shagina LA, Khlebnikova OV, Evgrafov OV. Mutation in the conexin 50 gene (GJA8) in a Russian family with zonular pulverulent cataract. Clin Genet. 2001;60(6): 476-8.

41. Conley YP, Erturk D, Keverline A, Mah TS, Keravala A, Barnes LR, et al. A juvenile-onset, progressive cataract locus on chromosome $3 q 21-q 22$ is associated with a missense mutation in the beaded filament structural protein-2. Am J Hum Genet. 2000;66(4):1426-31.

42. Jamieson RV Perveen R, Kerr B, Carette M, Yardley J, Heon E, et al. Domain disruption and mutation of the bZIP transcription factor, MAF, associared with cataract ocular segment dysgenesis and coloboma. Hum Mol Genet. 2002;11(1):33-42

43. Santana A, Waiswol M, Arcieri ES, Vanconcellos JP, Barbosa de Melo M. Mutation analysis of CRYAA, CRYGC, and CRYGD associated with autosomal dominant congenital cataract in Brazilian families. Mol Vis. 2009;15:793-800. 